\title{
Peran Masyarakat dalam Promosi Pariwisata Kota Singkawang
}

\author{
Widha Anistya Suwarso \\ Program Studi Ilmu Komunikasi, Fakultas Ilmu Sosial dan Ilmu Politik Universitas \\ Tanjungpura \\ Email:widha.as@fisip.untan.ac.id
}

\begin{abstract}
ABSTRAK
Pariwisata merupakan salah satu sektor unggulan dalam mendukung perekonomian di Indonesia. Keberadaan pariwisata di daerah selain menjadi pemasukan bagi pemerintah juga memberikan kesempatan bagi masyarakat untuk berinteraksi dan bertransaksi dengan para wisatawan. Sehingga pengembangan pariwisata di daerah bukan semata tanggung jawab pemerintah, tetapi juga perlu didukung oleh masyarakat. Penelitian ini bertujuan untuk mengidentifikasi peran masyarakat dalam promosi pariwisata Kota Singkawang. Promosi pariwisata merupakan bentuk komunikasi pemasaran dalam pariwisata yang tujuannya untuk memengaruhi target wisatawan agar berkunjung ke daerah wisata yang dipromosikan. Tujuan dari promosi secara spesifik adalah untuk menginformasikan (to inform) dan untuk mempengaruhi (to persuade). Bentuk-bentuk promosi yang dikenal sebagai bauran promosi terdiri dari personal selling, mass selling, promosi penjualan, public relations, dan direct marketing. Jenis penelitian ini adalah deskriptif dengan pendekatan kualitatif. Melalui metode ini peneliti berusaha mengidentifikasi dan mendeskripsikan peran masyarakat dalam promosi pariwisata di Kota Singkawang. Pengumpulan data dilakukan melalui wawancara mendalam dan observasi. Hasil penelitian menunjukkan, peran masyarakat dalam promosi pariwisata Kota Singkawang dapat diidentifikasi sebagai berikut: 1) mengelola tempat wisata; 2) mengelola media informasi; 3) menciptakan dan memelihara iklim sosial yang kondusif; dan 4) melakukan promosi melalui media sosial. Untuk memaksimalkan peran masyarakat, diharapkan pemerintah lebih proaktif dalam merangkul para penggiat dan masyarakat umum yang terlibat dalam promosi pariwisata Kota Singkawang.
\end{abstract}

Kata kunci: Peran Msyarakat, Promosi Pariwisata, Kota Singkawang

\section{The Role of Community to the Tourism Promotion in Singkawang City}

\begin{abstract}
Tourism is one of the leading sectors in supporting the economy in Indonesia. The existence of tourism in the area besides being an income for the government also provides opportunities for the community tointeract and transact with tourists. So that the development of tourism in the regions is not only the responsibility of the government, but also needs to be supported by the community. This study aims to identify the role of the community in promoting tourism in the City of Singkawang. Tourism promotion is a form of marketing communication in tourism which aims to influence target tourists to visit the promoted tourist area. Specifically, the purpose of promotion is to inform (to inform) and to influence (to persuade). The forms of promotion known as promotion mix consist of personal selling, mass selling, sales promotion, public relations, and direct marketing. This type of research is descriptive with a qualitative approach. Through this method the researcher tries to identify and describe the role of the community in promoting tourism in Singkawang City. Data collection was carried out through in-depth interviews and observations. The results showed that the role of the community in promoting tourism in Singkawang City can be identified as follows: 1) managing tourist attractions; 2) managing information media; 3) creating and maintaining a conducive social climate; and 4) promoting through social media. To maximize the role of the community, it is hoped that the government will be more proactive in embracing activists and the general public who are involved in promoting tourism in Singkawang City. Keywords: Community Role, Tourism Promotion, Singkawang City
\end{abstract}

Published: Maret 2021

ISSN: 2622-5476 (cetak), ISSN: 2655-6405 (online) Website: https://jurnal.amikom.ac.id/index.php/pikma 


\section{PENDAHULUAN}

Pariwisata merupakan salah satu sektor unggulan dalam mendukung perekonomian di Indonesia. Indonesia memiliki potensi yang besar di bidang pariwisata karena potensi alam dan budaya yang begitu kaya. Keberadaan pariwisata di daerah selain menjadi pemasukan bagi pemerintah juga memberikan kesempatan bagi masyarakat untuk berinteraksi dan bertransaksi dengan para wisatawan. Salah satu destinasi wisata yang cukup populer di Indonesia adalah Kota Singkawang, yang terletak 145 km di utara Kota Pontianak, ibukota Provinsi Kalimantan Barat. Kota yang dijuluki dengan sebutan kota paling toleran seIndonesia ini terkenal sebagai kota wisata budaya, Setiap tahun wisatawan domestik maupun mancanegara berdatangan untuk menyaksikan kemeriahan Festival Cap Go Meh. Festival ini merupakan sebuah atraksi yang menjadi perwujudan akulturasi dari etnis-etnis besar yang ada di Kota Singkawang. Festival inilah yang kemudian menjadi daya tarik utama Kota Singkawang sebagai destinasi wisata budaya.

Acara puncak perayaan Cap Go Meh di Kota Singkawang pada tahun 2019, mendatangkan lebih dari 70.000 wisatawan (Dimyati, 2019). Mengingat pariwisata adalah salah satu sektor unggulan dalam mendukung perekonomian, keberadaan pariwisata di daerah selain menjadi pemasukan bagi pemerintah juga memberikan kesempatan bagi masyarakat untuk berinteraksi dan bertransaksi dengan para wisatawan. Menurut Ismayanti (2009:1) masyarakat penerima wisatawan dapat terlibat secara langsung dan aktif dalam dunia pariwisata misalnya sebagai karyawan sementara atau tetap di industri penyedia jasa pelayanan pariwisata seperti; biro perjalanan wisata (travel agency), hotel, villa, bungalow, restoran, transportasi dan lain sebagainya (dalam Sembiring, 2016). Oleh karenanya, kemasyhuran wisata budaya yang dimiliki Kota Singkawang diharapkan mampu mendongkrak daya tarik pariwisata lain yang sangat potensial, seperti wisata alam dan wisata kuliner (Oxtora, 2019).

Guna mewujudkan hal tersebut tentu dibutuhkan berbagai upaya untuk mengoomunikasikan potensi pariwisata yang ada. Komunikasi membantu pemasaran pariwisata, komunikasi berperan menyiapkan pesan yang harus disampaikan kepada masyarakat atau wisatawan, tentang apa yang seharusnya diketahui oleh wisatawan (Linasari dkk., 2016). Bentuk dari komunikasi yang sangat penting dalam sebuah kegiatan pemasaran adalah promosi. Promosi diartikan sebagai aktivitas komunikasi yang berguna menyebarkan informasi, mempengaruhi/membujuk, dan 
mengingatkan target sasaran untuk loyal kepada produk yang ditawarkan (Tjiptono dalam Mayasari, 2014).

Kegiatan promosi pariwisata yang dilakukan tentu saja memiliki tujuan yang menurut Setiadi (2003:266) sebagaimana dikutip oleh Herat dkk. (2015) adalah sebagai berikut: 1) Untuk menginformasikan (to inform). Kegiatan menginformasikan ini ditujukan kepada Publik mengenai potensi Pariwisata yang ada dalam rangka memperkenalkan tentang keberadaan potensi Pariwisata serta menjelaskan aspek-aspek apa saja yang berkaitan dengan potensi Pariwisata yang ada; dan 2) Untuk mempengaruhi (to persuade). Kegiatan mempengaruhi ini dilakukan guna mendorong terbentuknya minat atau keinginan Publik. Pesan yang disampaikan harus mampu mempersuasi khalayak agar timbul minat untuk mengenal lebih dekat potensi pariwisata yang ada, mendorong khalayak untuk bisa mengunjungi langsung serta mampu juga menarik pihak ketiga yaitu investor untuk lebih mempromosikan produk/jasa kita.

Promosi merupakan unsur utama dalam kegiatan yang mencoba menggugah kesadaran publik untuk melakukan atau menginginkan sesuatu. Menurut Sunaryo (dalam Herat dkk., 2015) aktivitas promosi kepariwisataan secara prinsip merupakan kegiatan komunikasi, yang dilakukan oleh organisasi penyelenggara pariwisata (destinasi) yang berusaha mempengaruhi khalayak atau pasar wisatawan yang merupakan tumpuan atau sasaran dari penjualan produk wisatanya. Mengacu pada pemahaman tersebut, maka masyarakat lokal sudah semestinya turut menjadi bagian dari promosi pariwisata bagi daerahnya.

Sejalan dengan hal tersebut, Soekadijo (dalam Mayasari, 2014) menjelaskan bahwa kegiatan promosi memiliki dua macam promosi, yaitu: 1) Promosi langsung (consumer promotion), dilakukan oleh semua lembaga yang bersangkutan dengan pemasaran; dan 2) Promosi tidak langsung (dealer promotion), ditujukan kepada penyalur produk pariwisata, seperti biro perjalanan umum dan cabangcabangnya, agen perjalanan, organisasi perjalanan dan sebagainya.

Secara keseluruhan bentuk-bentuk promosi memiliki fungsi yang sama tetapi dapat dibedakan berdasarkan tugas-tugas khususnya yang dikenal sebagai bauran promosi (promotion mix, promotion blend, communication mix) yaitu: personal selling, mass selling yang terdiri atas periklanan dan publisitas, promosi penjualan, public relations (hubungan masyarakat), dan direct marketing (Tjiptono dalam Mayasari, 2014). 
Mengingat begitu banyak pihak yang terlibat dalam pengembangan pariwisata, maka poromosi pariwisata sebagai bentuk komunikasi pemasaran atas pariwisata juga menjadi bagian dari tugas para pihak yang berkepentingan. Selama ini penelitian tentang promosi pariwisata di daerah lebih banyak fokus pada peran pemerintah, diantaranya penelitian yang dilakukan oleh Mayasari (2014), Herat dkk. (2015), Linasari dkk. (2016), dan Sembiring (2016). Penelitian-penelitian tersebut mendeskripsikan promosi pariwisata di daerah oleh instansi pemerintah yang berwenang. Oleh karena itu peneliti tertarik untuk melengkapi kajian promosi pariwisata di daerah dengan melihat dari perspektif berbeda. Penelitian ini menitikberatkan tentang bagaimana masyarakat umum mengambil peran dalam kegiatan promosi pariwisata di daerahnya.

\section{METODOLOGI}

Penelitian ini merupakan jenis penelitian deskriptif dengan pendekatan kualitatif. Metode penelitian deskriptif kualitatif hanya memaparkan situasi atau peristiwa, tidak mencari dan menjelaskan hubungan, tidak menguji hipotesis atau membuat prediksi (Rakhmat, 2009:24). Metode ini dinilai sebagai yang paling sesuai oleh peneliti untuk menggambarkan bagaimana masayarakat mengambil peran dalam promosi pariwisata Kota Singkawang.

Penelitian dilakukan di Kota Singkawang pada rentang waktu JuliSeptember 2019. Subjek penelitian ini adalah masyarakat Kota Singkawang dengan latar belakang yang beragam sehingga dapat mewakili kondisi masyarakat yang majemuk. Sedangkan objek penelitian adalah peran masyarakat dalam mempromosikan pariwisata Kota Singkawang.

Kegiatan pengumpulan data adalah prosedur yang sangat menentukan baik atau buruknya kualitas sebuah penelitian (Kriyantono, 2010:95). Data dalam penelitian ini diperoleh melalui wawancara mendalam dan observasi. Informan dalam penelitian ini ditentukan dengan purposive sampling, artinya informan yang dipilih merupakan orang-orang yang dianggap menguasai masalah penelitian. Wawancara dilakukan dengan penggiat komunitas pariwisata, penggiat media sosial, putri pariwisata, dan masyarakat umum. Observasi dilakukan secara online dengan mengamati akun media sosial yang dikelola oleh informan maupun akun pribadi mereka.

Semua data yang diperoleh diolah dengan teknik analisis data interaktif menurut Miles dan Huberman yang terdiri dari proses pengumpulan data, reduksi data, 
penyajian data, dan verifikasi data/penarikan kesimpulan (Bungin, 2008:69).

\section{HASIL DAN PEMBAHASAN}

Kota Singkawang yang selama ini tersohor sebagai destinasi wisata budaya, sejatinya masih menyimpan banyak potensi wisata lainnya seperti wisata alam dan wisata kuliner. Dengan promosi yang efektif, daya tarik yang begitu besar ini semestinya mampu diekspos dan mendatangkan banyak wisatawan. Hasil penelitian ini menunjukkan, tidak semua bentuk promotion mix yang terdiri dari personal selling, mass selling, promosi penjualan, public relations dan direct marketing melibatkan masyarakat di dalamnya. Mass selling yang terdiri dari dari periklanann dan publisitas, serta public relation lebih banyak dilakukan oleh pemerintah sebagai lembaga yang memiliki kewenangan dalam pengelolaan pariwisata di daerah. Kegiatan promosi personal selling, promosi penjualan, dan direct marketing banyak dilakukan oleh masyarakat, terutama yang terlibat sebagai pelaku usaha seperti perhotelan, restoran, dan transportasi. Sedangkan masyarakat secara umum lebih aktif terlibat dalam personal selling dengan melakukan promosi secara mandiri. Secara lengkap, peran yang dimainkan oleh masyarakat dalam promosi pariwisata Kota Singkawang dibagi dalam beberapa bentuk, yaitu:

\section{Mengelola Tempat Wisata}

Kota Singkawang yang menjadi identik dengan Festival Cap Go Meh mampu menyedot perhatian wisatawan lokal dan mancanegara. Momentum ini idealnya dapat digunakan untuk mempromosikan potensi wisata Kota Singkawang lainnya. Meski begitu, festival yang hanya dilaksanakan setahun sekali ini, belum cukup untuk menjadi penopang potensi wisata Kota Singkawang. Potensi alam sebagai tujuan wisata juga seharusnya menjadi perhatian pemerintah maupun sektor swasta untuk dikelola dengan baik dan dipromosikan dengan komunikasi pemasaran yang tepat.

Salah satu contoh peran nyata masyarakat dalam pengembangan potensi wisata alam dapat kita jumpai di Setapuk Mangrove Park. Kawasan Mangrove Park di Setapuk ini pada awalnya diinisiasi oleh komunitas yang ada di Singkawang yang didukung oleh Komunitas dari Pontianak dengan inisiator Benny Thanheri yang beberapa tahun lalu membawa bibit mangrove bantuan dari Bank Indonesia. Seiring berjalannya waktu, kawasan mangrove itu kemudian diambil alih oleh Balai Pengelolaan Sumber Daya Pesisir dan 
Laut (BPSPL) Kota Pontianak dan diserahkan pengelolaannya kepada Dinas Pariwisata Kota Singkawang dan masyarakat sekitar kawasan tersebut melalui kelompok masyarakat Surya Perdana Mandiri Desa Setapuk.

Pengelolaan oleh masyarakat menjadi sebuah hal baik untuk meningkatkan partisipasi masyarakat dan memupuk rasa memiliki (sense of belonging), sehingga keberadaan kawasan wisata, bukan hanya dinikmati sebagai sebuah lokasi yang dikunjungi wisatawan, melainkan juga menjadi lahan pemberdayaan masyarakat. Meski begitu, pengelolaan yang dilakukan oleh masyarakat tidak serta merta menjadikan kawasan ini secara otomatis mendatangkan pengunjung. Trino Junaidi, penggiat ekonomi kreatif, menilai dengan melihat kondisi Setapuk Mangrove Park sekarang masih jauh untuk dijadikan sebagai salah satu destinasi wisata unggulan.

"Wisata alam Singkawang masih jauh dari tetangganya sendiri, Bengkayang. Bengkayang dengan segudang wisata alamnya tentunya sangat menarik perhatian wisatawan untuk berkunjung ke sana. Sementara di Singkawang, beberapa objek wisata masih banyak kekurangan terutama dari segi fasilitas pendukungnya." (Wawancara 19 Juli 2019)

Lebih lanjut, Trino menjelaskan tampaknya pemerintah dan masyarakat terutama pihak komunitas masih tidak sepaham. Di satu sisi, pemerintah memandang, sebagai objek wisata alam yang baru saja diresmikan Walikota, Setapuk Mangrove Park bisa menjadi daya Tarik pariwisata andalan dalam mewujudkan Instruksi Walikota agar tahun 2019 bisa mendatangkan 50.000 wisatawan ke Singkawang. Sedangkan di lain sisi, Setapuk Mangrove Park yang masih minim fasilitas publik (tempat beristirahat, rumah makan, lahan parkir, tempat sampah) dan pengelolaannya menurut Trino masih belum memadai untuk dijadikan unggulan.

Riko, salah satu warga Kota Singkawang yang merupakan seorang Pegawai Negeri Sipil (PNS) memandang bahwa seharusnya pemerintah mengambil peran yang signifikan dalam pengembangan pariwisata. Riko mengatakan,

"Peran pemerintah dalam upaya promosi pariwisata adalah membuat program pembangunan pariwisata, kemudian juga menetapkan kebijakan dan regulasi pariwisata dan saling bekerja sama dengan stakeholder dan pihak pengembang" (Wawancara 1 Agustus 2019)

\section{Mengelola Media Informasi}

Hal yang tidak kalah penting dalam melakukan kegiatan promosi pariwisata adalah keberadaan media. Bukan hanya terbatas pada media massa, tetapi juga media sosial. Media memiliki pengaruh yang besar dalam pengembangan dan 
promosi pariwisata sebab media adalah sumber informasi bagi wisatawan dan calon wisatawan yang turut melandasi keputusan tujuan wisata yang akan mereka pilih.

Promosi melalui media tidak hanya dilakukan oleh pemerintah melalui tagline Ayo ke Singkawang! tetapi juga masyarakat. Salah satunya akun Instagram @singkawanginformation yang dipelopori oleh Kasnur berisi banyak informasi yang berhubungan dengan promosi pariwisata Kota Singkawang.

"Pelaku swasta sangat lah berpengaruh mengambil alih dalam hal pembangunan dan promosi wisata, salah satunya media, media akan menjadi pengaruh besar dalam dunia promosi wisata di kota singkawang, Media akan menjadi sektor utama bagi calon wisatawan mendapatkan informasi dan mengambil langkah menentukan keputusan tujuan wisata." (Wawancara 3 Agustus 2019).

Kasnur membangun dan menggerakkan@singkawanginformation sejak tahun 2017 yang diharapkan dapat mempromosikan pariwisata Kota Singkawang sekaligus menjadi ruang berinteraksi penuh toleransi, mengingat pengikut media yang terdiri dari beragam karakteristik.

Sebagai seorang penggiat media, Kasnur menyadari televisi juga merupakan media yang efektif untuk promosi. Kemudian Kasnur juga memilih TV lokal sebagai saluran promosi pariwisata Kota
Singkawang. Penjelasan KAsnur selengkapnya:

"Tahun 2019, kami juga membangun kantor produksi media sendiri Singkawang Information dan juga menjadi alih dalam kolaborasi dengan PT. Kabel Singkawang Vision, untuk menahkodai TV lokal Singkawang dengan Saluran Channel 57 di TV Kabel Singkawang Vision, saluran lokal ini berorientasi dalam pembangunan promosi wisata, kreativitas, dan berita daerah." (Wawancara 3 Agustus 2019)

Keberadaan saluran televisi lokal diharapkan dapat mendukung promosi Kota Singkawang melalui konten-konten lokal dan berita daerah. destinasi wisata maupun potensi wisata merupakan unsur lokalitas yang harus diangkat serta dipromosikan. TV Lokal juga semakin mempermudah akses promosi dari pihak-pihak yang terkait dengan pengelolaan pariwisata.

\section{Menciptakan dan Memelihara Iklim}

\section{Sosial yang Kondusif}

Masyarakat Kota Singkawang harus tetap menjaga keamanan dan kenyamanan sehingga siapapun yang berkunjung merasa senang dan menceritakan pengalaman tersebut sehingga orang lain ikut tertarik untuk berkunjung. Menurut Yuni Maulina, Putri Pariwisata Singkawang tahun 2017, pentingnya peran masyarakat dalam menciptakan dan memelihara iklim yang kondusif untuk mengembangkan pariwisata sangat sesuai dengan konsep Sapta Pesona 
yang merupakan jargon pariwisata Indonesia. 7 Unsur sapta pesona yaitu keamanan, ketertiban, kebersihan, kesejukan, keindahan, keramahan, dan kenangan. Sapta pesona merupakan jabaran konsep sadar wisata, terutama berkaitan dengan dukungan dan peran serta masyarakat sebagai tuan rumah yang mendorong tumbuh dan berkembangnya industri pariwisata.

Masyarakat lokal harus berupaya menjaga iklim kondusif terutama dalam kehidupan bermasayrakat. Sikap toleransi atas keberagaman harus terjaga dan terus dipelihara. Hal ini penting berkaitan dengan Kota Singkawang yang terkenal sebagai salah satu kota paling toleran di Indonesia. Beragam etnis hidup berdampingan secara harmonis dan menjadi daya tarik wisata budaya. Berikut pernyataan Yuni Maulina:

"Ya.. Kota Singkawang memang dikenal salah satu kota toleransi di Indonesia.. Tentu menjadi suatu kebanggaan sетиа masyarakat karena terdapat berbagai macam suku dan agama yang ada di Kota Singkawang. Dengan adanya perbedaan tidak membuat Kota Singkawang terpecah belah tapi tetap membuat Kota Singkawang selalu damai dan bersatu. Masyarakat lokal harus berupaya memaksimalkan iklim yang baik dalam hidup bermasyarakat, sikap toleransi dan keberagaman harus di pertahankan dan di tingkatkan... Agar wisatawan selalu tertarik untuk pergi ke Kota Singkawang. " (Wawancara 31 Juli 2019)

\section{Melakukan Promosi Melalui Media Sosial}

Setiap individu merupakan bagian dari masyarakat yang bisa turut andil sebagai komunikator dalam mempromosikan pariwisata Kota Singkawang. Secara pribadi, setiap orang dapat mempromosikan pariwisata di daerahnya melalui unggahan pada akun media sosial miliknya. Penggunaan media sosial sebagai ajang promosi, menjadi hal yang relatif mudah dan murah dalam memperkenalkan Kota Singkawang.

Individu dapat berkontribusi dengan cara mengeksplorasi tempat wisata di Kota Singkawang kemudian mengunggahnya di akun pribadi. Sejauh ini, kebanyakan masyarakat akan memanfaatkan media sosial mereka untuk mendukung promosi pariwisata Kota Singkawang. Seperti yang dilakukan Penny, seorang banker, ia mengunjungi tempat wisata untuk mengisi hari liburnya dan mengunggah potret liburan tersebut ke akun Instagram miliknya. Berikut penuturan Penny:

"Dalam hal ini saya sebagai masyarakat lokal mengunjungi beberapa tempat wisata ketika libur tiba, kemudian saya unggah potret liburan ke akun Instagram dan share lokasi dimana saya sedang kuliner atau mengunjungi tempat wisata. Hal ini berupaya untuk mendapat feedback bagi pengikut di sosial media saya supaya tertarik mengunjungi tempat tersebut." (Wawancara 22 Juli 2019). 
Penny bahkan merekomendasikan tempat berlibur di Singkawang yang menarik bagi wisatawan, salah satunya yaitu Kahyangan Resort dengan tempat yang instagramable dan adorable memberikan penginapan terbaik bak wisata di Bali dengan suguhan panorama laut. Setelah mengunggah konten berisikan promosi pariwisata tentu yang diharapkan adanya feedback dari pengguna lain yang boleh jadi akan menjadi calon wisatawan Kota Singkawang di masa mendatang.

Aktivitas promosi kepariwisataan secara prinsip merupakan kegiatan komunikasi, yang dilakukan oleh organisasi penyelenggara pariwisata (destinasi) yang berusaha mempengaruhi khalayak atau pasar wisatawan yang merupakan tumpuan atau sasaran dari penjualan produk wisatanya (Sunaryo dalam Herat dkk., 2015). Berdasarkan pemahaman tersebut, maka sekecil apa pun peran yang dilakukan oleh masyarakat sepanjang bertujuan untuk mempengaruhi khalayak agar berminat untuk berkunjung ke destinasi wisata Kota Singkawang merupakan bentuk promosi pariwisata yang perlu diperhitungkan.

\section{KESIMPULAN}

Sektor pariwisata hanya dapat dikembangkan jika adanya sinergi antara berbagai pihak, yaitu pemerintah, pelaku usaha (swasta), dan masyarakat yang melibatkan semua kegiatan komunikasi yang memungkinkan untuk secara maksimal dapat menjaring dan mendatangkan wisatawan. Upaya mempromosikan pariwisata jelas membutuhkan strategi yang kuat dan kerjasama diantara para pihak yang terlibat. Dari sisi masyarakat, peran yang dilakukan tentu saja berkaitan dengan kemampuan yang dimiliki dan dilakukan secara berkelanjutan. Hasil penelitian menunjukkan bahwa peran masyarakat dalam promosi pariwisata Kota Singkawang adalah: 1) mengelola tempat wisata; 2) mengelola media informasi; 3) menciptakan dan memelihara iklim sosial yang kondusif; dan 4) melakukan promosi melalui media sosial.

Dengan peran yang sejauh ini telah dilakukan masyarakat, hendaknya pemerintah lebih proaktif dalam merangkul penggiat-penggiat di berbagai sektor dan juga masyarakat umum yang ikut terlibat dalam mempromosikan pariwisata Kota Singkawang agar tujuan promosi bisa tercapai. Di sisi lain, pengelola wisata juga diharapkan lebih aktif dalam mengembangkan potensi wisata yang ada di daerah sehingga para wisatawan akan datang dan datang lagi. Masyarakat juga diharapkan lebih aktif dalam memanfaatkan perkembangan teknologi 
dalam promosi pariwisata Kota Singkawang, misalnya selalu men-tag akun media sosial pemerintah maupun pengelola wisata setiap kali mengunggah konten yang berkaitan dengan pariwisata Kota Singkawang.

\section{DAFTAR PUSTAKA}

Bungin, Burhan. (2008). Analisis Data Penelitian Kualitatif. Jakarta: Raja Grafindo Persada.

Dimyati, Vien. (2019, Februari 19). Perayaan Cap Go Meh Singkawang Sukses Gaet Wisatawan Mancanegara. iNewa.id. Diakses dari https://www.inews.id/travel/destinasi/pera yaan-cap-go-meh-singkawang-suksesgaet-wisatawan-mancanegara/464525.

Herat, Rizki Andini dkk. (2015). Peran Bidang Promosi Dan Pemasaran Dinas Pariwisata Kabupaten Pulau Morotai Dalam Mempromosikan Potensi Pariwisata Kabupaten Pulau Morotai. E-journal Acta Diurna, 4 (4). Diperoleh melalui https://media.neliti.com/media/publication s/89559-ID-peran-bidang-promosi-danpemasaran-dinas.pdf

Kriyantono, Rakhmat. (2010). Teknik Praktis Riset Komunikasi. Jakarta: Kencana.

Linasari, Festi dkk. (2014). Komunikasi Pemasaran Pariwisata Dan Kunjungan Wisatawan Di Bangkalan. Diperoleh melalui jurnal.untagsby.ac.id/index.php/representamen/article/ download/1455/1243

Mayasari, Dianoor. (2014). Strategi Promosi Pariwisata Pulau Derawan (Studi Deskriptif Kualitatif Strategi Promosi
Dinas Pariwisita Kabupaten Berau Kalimantan Timur Dalam Upaya Menjadikan Pulau Derawan Sebagai Tujuan Wisata). Skripsi. Universitas Muhammadiyah Surakarta. Diperoleh melalui http://eprints.ums.ac.id/39811/1/NASKAH \%20PUBLIKASI.pdf

Oxtora, Rendra. (2019, Februari 19). Menpar siap angkat pariwisata Singkawang jadi kelas dunia. Antara Kalbar. Diakses dari https://kalbar.antaranews.com/berita/3739 23/menpar-siap-angkat-pariwisatasingkawang-jadi-kelas-dunia

Rakhmat, Jalaludin. (2009). Metode Penelitian Komunikasi. Bandung: PT Remaja Rosdakarya

Sembiring, Junaidi Pranata. (2016). Strategi Komunikasi Pemasaran Objek Wisata Gundaling dan Pemandian Air Panas Semangat Gunung. Jurnal Simbolika, 2 (1), 1-22. Diperoleh melalui https://ojs.uma.ac.id/index.php/article/dow nload/223/171

Rcfra.org. (2021). https://rcfra.org/2021/03/19/5-besarplatform-media-sosial-terfavorit-diindonesia/

Rishika, R., Kumar, A., Janakiraman, R., \& Bezawada, R. (2013). The effect of customers' social media participation on customer visit frequency and profitability: an empirical investigation. Information systems research, 24(1), 108-127.

Suharso, P. (2019). Pemanfaatan Drone Emprit dalam Melihat Trend Perkembangan Bacaan Digital 
Jurnal PIKMA: Publikasi Media Dan Cinema, Volume 3, No. 2, Maret 2021, hlm 146-156

melalui Akun Twitter. Anuva, 3(4),

$333-346$. 